\title{
ISO 9001 standard in the development of customer satisfaction in the public sector of Bosnia and Herzegovina
}

\author{
Dino Kakeš \\ Indirect Taxation Authority of Bosnia and Herzegovina, Banja Luka, Bosnia and \\ Herzegovina \\ dino_kakes@hotmail.com
}

Senad Fazlović

Faculty of Economics, University of Tuzla, Bosnia and Herzegovina

senad.fazlovic@untz.ba

\begin{abstract}
The concept of quality management in the public sector is nowadays more popular than ever before. Since it forms in the fields of public interest, public companies, institutions and organizations are crucially important for the development and the functioning of any social and modern society. Therefore, those organisations are expected to perform transparent, efficient, democratic and socially righteous work with the goal of maintaining and improving the quality of a nation's economic life. In Bosnia and Herzegovina, the public sector is specific and additionally complicated by a complex political system, legal procedures and the constitutional structure and as such, it is often very ineffective. The main purpose of the implementation of ISO 9001 is to introduce a system of quality management and improve the quality of public services as well as to ensure customer satisfaction. Therefore, the goal of this paper is to present the concept of customer satisfaction and selected statistical methods in quality management, and to apply a part of these methods through secondary research and analysis of published reports about customer satisfaction with services of the public sector in Bosnia and Herzegovina. Results of the study have confirmed greater user satisfaction with service in the public sector in units of local self-government with an implemented ISO 9001 standard implemented ISO 9001 standard than in units in which the standard has not been implemented.
\end{abstract}

Keywords: cluster sampling, independent samples, Levene's test, ISO 9001, public sector, user satisfaction.

JEL classification: C10, D73, H41.

DOI: 10.1515/crebss-2016-0008

Received: May 15, 2016

Accepted: August 25, 2016

\section{Introduction}

Customers' satisfaction is one of the basic principles in the work of each service organization, thus organizations from the public sector, however, it is often said that the commitment to quality is actually a commitment to the customer (user). Without 
the focus on citizens as service users, the purpose and commitment to the quality of public sector organizations becomes meaningless. In the profit-oriented enterprises, the degree of satisfaction of consumers and users of services largely determines the future business success of that company in the market because satisfied customers or users of services are precisely the force that generates most of the current and future operating revenues and those who create value for the organization (llić, Živković, 2001).

Very important aspect of this approach, systems for quality management promotes business policy based on consistent meeting of consumer's needs, wishes and demands. The international standard ISO 9001 notes necessity for defining and meeting requirements of users/consumers with the goal of increasing their satisfaction. According to the standard requirements, an organization must determine the requirements, which are specified by the user, including the requirements for delivery and requirements for activities after delivery. Without this, a commitment to the quality becomes meaningless since the product or service become useless if you do not have customers.

This paper wants to explore a principle of business direction of the public sector organisations towards citizens as the users of these services, and to identify areas of possible improvements of satisfaction of the public services users by implementing ISO 9001 standard.

As a base for exploring the impact of the implementation of quality management system on the level of satisfaction of users of public services served the project "Monitoring of public services at the local level-Citizens and local authority together to reach better services", which examined satisfaction of citizens in 25 units of local government at the state level of Bosnia and Herzegovina and to give their own contribution, the research was extended and amended with the results of its own examination of citizens' satisfaction with public services in five local government units with different degrees of development, urban and rural orientation and territorial diversity, by which we come to a total of 30 local government units covered by this research.

Based on such collected data, it will be examined a difference in users' satisfaction when it comes to quality, maintenance, access, availability, costs, regularity and timeliness of delivery in the BiH public sector. Besides introductory and concluding remarks, the paper is written using four interrelated parts. In the first part of the paper were presented some previous researches, while in the second part was presented theoretical basis of the customer's satisfaction as one of the basic principles in the work of the private and public sector organisations and in this part of the paper was presented basic statistical methods for managing quality in the phase of identification of users' wishes and needs; the third part of the paper will be dealing with analysis of the current situation when it comes to the operating of the public sector and the implementation of standard ISO 9001 in Bosnia and Herzegovina. The methodology and results of the research are presented in the fourth part of the paper.

\section{Literature review}

Until today, in the literature and practice there have been many debates about whether it is possible to transfer quality management from private sector into public adequately. Stringham (2004) gives an affirmative answer stressing that quality management can be very compatible to the management in the public sector despite the scepticism of some authors. Ramseook-Manhurrun, Lukea-Bhiwajee and Naidoo (2010) by examining the customer's satisfaction with the services of the 
public transport emphasized the importance of researching customer satisfaction with the quality of services, regardless of whether the organization has been operating in the private or public sector, pointing out that it is expected that the organization of the public sector continuously improves quality in order to surpass the expectations of their customers.

From the onset of the first theories and models of their measurements until now, the quality of services has remained closely linked to the definition and meaning of the concept of customer's satisfaction. Most often in research, especially in everyday speech these two categories are on the same level, however there are a number of authors who, on the other hand, point out that in fact it is about mutually dependent categories instead of identical categories. Boulding, Karla, Staelin and Zeithaml (1993) in their research come to the conclusion that customer satisfaction is not synonymous to the quality of services but it actually marks cumulative measure. Oliver makes a distinction between these two terms saying that the quality of service actually proceeds to customer satisfaction (Oliver, 1981), while Woodside, Frey and Daly see causality between these two categories in the opposite directions (Woodside, Frey, Daly, 1989). Gorji and Sargolaze (2011) in their research of dependence between service quality of an insurance companies and customer's satisfaction, which are categorised on to users of the private, and public sector came to conclusion that not all dimensions of service quality have the same impact on the satisfaction of users of these two categories.

When it comes to so far conducted researches in BiH, Huseinspahic (2010), let us say, evaluate the SERVQUAL model as valid and appropriate in assessing the experienced quality of health care services in the University Clinical Center Tuzla, and in his research he highlights the tangibles, reliability and safety as key dimensions by which it is possible to increase the perceived quality. Babić-Hodović and Činjarević apply SERVQUAL model in the field of public education, and by measuring the perception of education's service quality of Faculty of Economic Science in Sarajevo they have determined dimensions of quality that are by the opinion of users rated as the most important, but at the same time as dimensions with the largest deviations in the difference between the perceived and the expected quality, which is a clear signal for the administration in which direction it is necessary to act if we want to keep the current situation in the market and provide an advantage over the competition (Babić-Hodović, Činjarević, 2008). The same authors, by applying SERVPERF model, have shown different effects of certain quality dimensions to the students' loyalty for the institution of higher education (BabićHodović, Činjarević, 2009).

\section{Statistical methods of quality management in phases of identification the needs and desires of customers}

The customer, which buys a product or service, has certain needs and expectations to satisfy its needs with a purchased product or service. The attitude of the customer about the level of satisfaction with its needs and expectations is crucial for quality of product or service. Of course, the manufacturer must take into account the compatibility with the technical documentation, the quality of construction and reliability; however, the final word gives the user of the goods. It should bear in mind that under the term user of the product goes not only associates but also employees of the company as well, which use in their works half-products as phase products, which come from the previous phases (Šehić, 2002).

The same goes for public companies, since they are companies that are founded by the state or unit of local self-government, whose main task is to provide services to 
the citizens and general public. The interest of the citizens as taxpayers for the values such as quality, available service and service on-time, transparency in the work, impartiality of public administration, social justice, responsibility of public management, equal opportunities for all social groups, etc. imposes to public organizations the need for continually improving the quality of their service. This further leads to the need for defining and respecting the users' expectations especially in transition countries, where most citizens rely on the services of the public sector due to the general economic situation which does not allow a choice of private health care, private schools, colleges and other forms of purchasing public services. The above mentioned reasons point out to the importance of the implementation of quality systems into units of local self-governments. In fact, public sector organizations must begin directing its activities towards the needs of users, just as it is the case with the private sector.

Besides external users, internal users as well are very important for providing of the quality. In this sense, business ethics and social responsibility, safety at work, health care, environmental awareness, exchange of information about the quality within the organization and similar procedures are also part of orientation towards users.

Customer's satisfaction is related to the needs and desires of users, considering that these are mutually dependent categories. It is therefore of great importance to test the needs and desires in order to adjust and reshape the public services according to the obtained information.

Quality Function Deployment (QFD) was developed in Japan. It involves incorporation of wishes and needs of users in the design of products and services. It is based on a set of matrices, in which the basic matrix connects the needs and wishes of the users on one side and their corresponding technical demands on the other. Often to the basic matrix are added weights of the importance of individual user's requirements, the correlation matrix of individual technical requirements and assessment of the competition, therefore including the constituent elements it is possible to construct a set of matrices known by the term "house of quality".

Customer needs analysis is the attempt and effort of complete quality management, which in relation to users tries to obtain the specific answer to questions such as:

- What are the main outputs of your own production process?

- Who are our customers, internal as well as external ones for the each of the above outputs?

- What are by the opinion of the users' main quality characteristics of certain outputs?

- How to measure the performance of these characteristics and in particular the key ones?

- Which objectives, considering these criteria would be satisfying for the desires and needs of consumers? (Skoko, 2000, 186)

In this regard, an important role may have the complaints from users. Complaints of citizens on the work of local self-governments in $\mathrm{BiH}$ are ensured by law regulations. Specifically, Article 46 of the Law on Principles of Local Self-Government in the Federation of Bosnia and Herzegovina ("Official Gazette of Federation of BiH", no. 49/06) and Article 80 of the Law on Local Self-Government in the Republic of Serbia ("Official Gazette of the Republic of Serbia", no. 101/04) prescribes the duty of the authority of local self-governments to provide citizens and legal entities to submit letters and complaints on their work as well as the work of their institutions and bodies, and the improper behaviours of employees in these institutions. On the 
submitted petitions and complaints, authorities of local self-governments are obliged to answer within 30 days of their submission.

Questionnaire user / supplier is an effort of the organization to, through separate questions for users on one side and suppliers on the other, set questions for itself and at the same try to objectively answer, in order to identify the main constraints that stand in the way of meeting the needs of users, and determine activities aiming to satisfy as many their demands as it is possible.

Customer/supplier model usually presents a graphical representation of the interrelationship between public sector organizations, citizens as well as its customers and suppliers.

Flowchart is a graphical representation of phases and the actual functioning of a certain process of providing public services to, through an analysis of their interconnection, identify the causes of the difficulties and possibilities of improving the quality of the process.

\section{The analysis of the current situation in BiH public sector and implementation of the standard ISO 9001}

In Bosnia and Herzegovina, a huge public sector inherited from the socialist period, in addition furtherly increased thanks to the complex constitutional architecture created by the Dayton Peace Agreement, according to many conducted analyses is often ineffective. To pay attention to the unnatural expansion of the public sector, along with increased administrative expenditures and reduced quality of products and services, warned Us, back in 2009, a report entitled "Corruption in Bosnia and Herzegovina" published by Transparency International BiH (Korupcija U Bosni i Hercegovini, 2009). In the context of the economic cost of corruption, this Report, among others highlights the following implications regarding the operations of the public sector:

- increased administrative expenses (BiH has the highest government expenditure in the transitional world, almost $50 \%$ of GDP per annum);

- unnatural expansion of the public sector (public sector remains the largest employment generator, and bureaucracy invents additional procedures in order to multiple itself, that is to create new jobs);

- reduction in the quality of goods and services (senior administrative expenses lead to a lower quality of goods and services, both in the private and public sector of Bosnia and Herzegovina).

A business transparency in local government, as one of the basic principles of operation of the public sector, is evidenced by a document "Research findings on the transparency of local self-governments in Bosnia and Herzegovina 2012" (Nalazi istraživanja o transparentnosti jedinica lokalne samouprave $\cup$ Bosni i Hercegovini, 2012). Basic elements of the units of the local government integrity are leaning on to several segments, and the current situation of transparency is analysed in terms of the work of the local Assembly and local government, cooperation with civil society and local institutions, and the existence of anti-corruptive mechanisms.

The research of the state and data collection by units of the local selfgovernments in $\mathrm{BiH}$ with the aim of determining the index of transparency was carried out between May and August 2012. During the research, there were no major problems, and data for 140 units of the local self-government were analysed, however there are no available data for Drvar and East Drvar.

The result was presented by an index of transparency, which is consisted of 100 indicators, and each of the indicators has value 1. Summing up all indicators, we come to the overall value of an index of transparency. Final results indicating that 
$80,58 \%$ of the total number of analysed local self-governments belongs to the group "partially transparent", while there was only one case of "transparency" of the local government (which itself is on the border between the "transparent" and "partially transparent" unit). Other units of local government are classified in the category of "non-transparent" and "extremely non-transparent".

Number of local units of local self-government according to categories of transparency observed from the entity level is presented in the Table 1.

Table 1 Number of local units of local self-government according to categories of transparency

\begin{tabular}{|l|c|c|c|}
\hline Category & $\mathrm{FBiH}$ & $\mathrm{RS}$ & Brčko Distrikt BiH \\
\hline Transparent & - & 1 & - \\
Partially transparent & 63 & 48 & 1 \\
Non-transparent & 12 & 10 & - \\
Extremely non-transparent & 3 & 2 & - \\
\hline
\end{tabular}

Source: Transparency International Bosna i Hercegovina (2012). pp. 16.

The report presented also the ranking list of municipalities in BiH according to the established criteria of the transparency index, which can be the basis for the implementation of benchmarking in the units of local self-government in the future period. In Table 2 are shown ten highest and lowest ranked municipalities with corresponding transparency indexes.

The strategic plan for the development of local self-government also identifies problems in quality, customer's dissatisfaction and burden of unnecessary costs of services, which is the responsibility of the local government, especially in the area of utilities, and administrative services (Strateški plan razvoja lokalne samouprave u BiH, 2006, Development Agency EDA Banja Luka). In an effort to change this situation, as one of the strategic objectives, plan sets the establishment of a sustainable process of improvement and implementation of appropriate systems to ensure continuous improvement in the quality and effectiveness of services, which is the responsibility of the local government. The strategic goal is further divided into the four operational objectives. One of them means introduction of appropriate quality management systems in organizations that provide public services at the local level.

Table 2 The ten highest and lowest ranked municipalities according transparency index (TI)

\begin{tabular}{|r|l|c|c|l|c|}
\hline \multicolumn{3}{|c|}{ The highest ranked municipalities } & \multicolumn{3}{c|}{ The lowest ranked municipalities } \\
\hline Rank & Municipality & TI & Rank & \multicolumn{1}{|c|}{ Municipality } & TI \\
\hline 1 & Banja Luka & 76 & 131. & Oštra Luka & 42 \\
2 & Bijeljina & 74 & 132. & Šipovo & 42 \\
3 & Bihać & 70 & 133. & Teočak & 40 \\
4 & Ilidža & 70 & 134. & Bosansko Grahovo & 39 \\
5 & Zavidovići & 69 & 135. & Neum & 38 \\
6 & Maglaj & 69 & 136. & Istočni Mostar & 23 \\
7 & Teslić & 69 & 137. & Kupres RS & 21 \\
8 & Bratunac & 69 & 138. & Dobretić & 16 \\
9 & Bosanska Krupa & 68 & 139. & Jajce & 12 \\
10 & Rogatica & 68 & 140. & Kiseljak & 7 \\
\hline
\end{tabular}

Source: Transparency International Bosna i Hercegovina (2012). pp. 46-49.

Therefore, the quality of public services is not satisfactory, the process management in the public sector of Bosnia and Herzegovina is not quality, and there is many opened areas where improvements can be made. Resolution of this 
issue can be done through the appropriate constitutional amendments and reform of public administration as well as the conditions of European integration (Otajagić, 2011).

On the basis of the Law about Standardization in BiH ("Official Gazette of BiH", no. 19/01), and according to the Rules of Procedure for preparation, adoption and publication of BiH standards ("Official Gazette of BiH", no. 49/09), BiH standards up until today are prepared, issued and published by the Institute for Standardization of Bosnia and Herzegovina on the proposal of the technical committee. Through technical bodies, Institute has so far taken about 17.000 international and European standards. Out of the total number of standards, the highest number of them originated by using methods of declaration, while about 250 methods has been taken using method of translating. Today, through the Institute have been activated fifty technical committees from various fields of standardization. In the work of these committees haven engaged about 600 experts from various fields. Standardization in the field of quality management has been entrusted to the technical committee number 3. This includes quality systems, quality assurance and general follow-up procedures and standards, which ensure managing of the selection and use of standards in the field of committees work.

On its website, the Institute has established a database of certified organizations in $\mathrm{BiH}$, which every year is delivered to the ISO Central Secretariat that publishes this data in the publication ISO Survey of Certifications, and in this way, it informs all its members about the number of certified organizations in the member states. According to the data of the ISO organization that are published on the official website of the organization, in $\mathrm{BiH}$ by the end of 2014 was issued a total of 8.162 certificates of ISO 9001. As it was seen in Figure 1, after a slight growth in the first few years, a sharp increase in the number of certificates began in 2004, after which it was recorded an upward trend until the last two years, when it was recorded a decrease in the number of issued certificates.

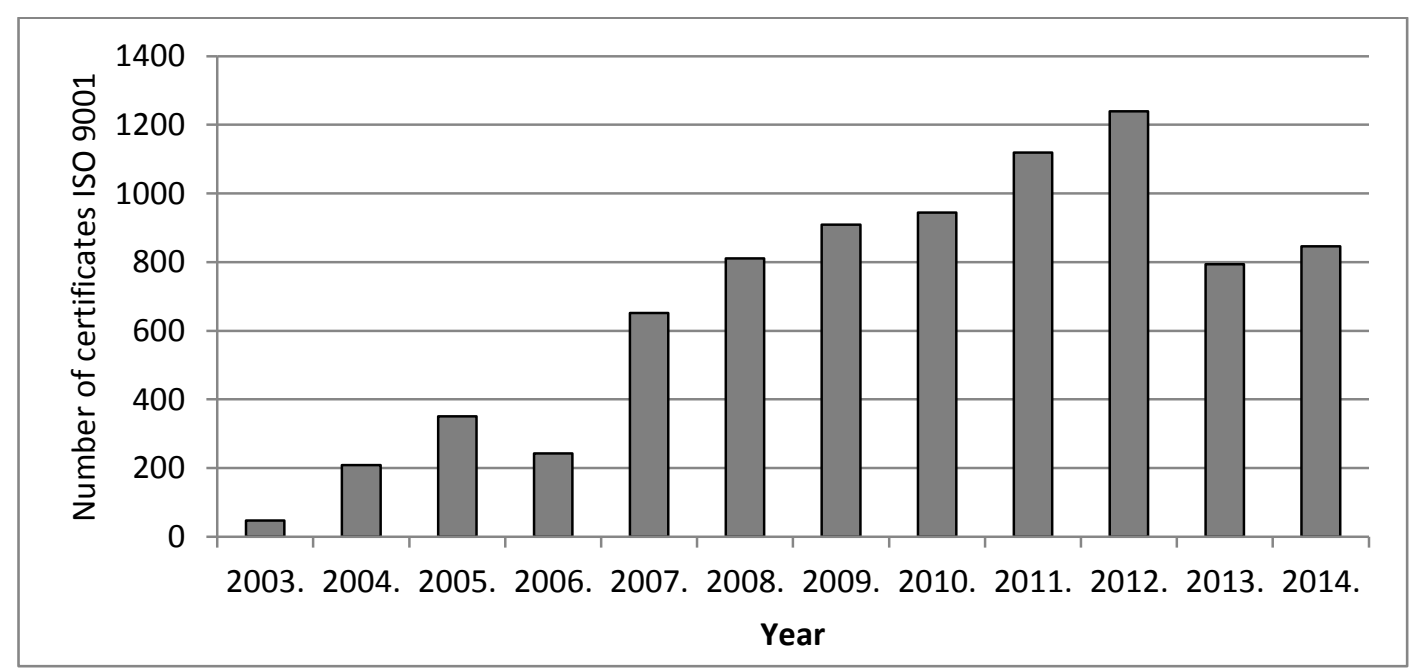

Figurel The number of certificates ISO 9001 issued in $\mathrm{BiH}$

Source: Authors' calculation based on ISO's data.

Of all countries, which were formed after breakup of Yugoslavia, Slovenia was the first that began with the certification activities, and therefore the first certificate of the ISO 9001 standard was issued back in 1989. Due to the specific political situation and social order, as well different years of recognizing some countries in our nearest habitat, and with the goal of making comparisons between the data, in Table 3 we 
are providing an overview of the number of certificates ISO 9001 issued in the countries emerged from the breakup of the former Yugoslavia between the period 2003 - 2014. According to the mentioned data, at the end of 2014, the highest number of certificates was issued in Croatia, followed by Serbia and Slovenia, while Bosnia and Herzegovina according to the number of issued certificates is above F.Y.R. Macedonia and Montenegro.

Table 3 The number of certificates ISO 9001 issued in the countries emerged from the breakup of the former Yugoslavia

\begin{tabular}{|c|c|c|c|c|c|c|}
\hline Year & BiH & Croatia & Montenegro & F.Y.R. Macedonia & Slovenia & Serbia \\
\hline 2003 & 47 & 580 & - & 47 & 465 & 103 \\
2004 & 209 & 966 & - & 133 & 1.811 & - \\
2005 & 350 & 1.273 & - & 154 & 2.114 & - \\
2006 & 242 & 1.676 & 33 & 217 & 2.182 & 1.551 \\
2007 & 652 & 2.073 & 136 & 255 & 1.886 & 1.987 \\
2008 & 811 & 2.302 & 160 & 271 & 1.945 & 2.091 \\
2009 & 909 & 2.567 & 157 & 295 & 1.688 & 2.733 \\
2010 & 944 & 2.102 & 85 & 333 & 1.701 & 1.790 \\
2011 & 1.119 & 2.117 & 146 & 290 & 1.658 & 3.228 \\
2012 & 1.239 & 2.584 & 102 & 396 & 1.595 & 2.750 \\
2013 & 794 & 2.636 & 118 & 399 & 1.993 & 2.366 \\
2014 & 846 & 2.807 & 130 & 446 & 1.672 & 2.637 \\
\hline Total & 8.162 & 23.683 & 1.067 & 3.236 & 20.710 & 21.236 \\
\hline
\end{tabular}

Source: Authors' calculation based on ISO's data.

According to the mentioned data, at the end of 2014, the highest number of certificates was issued in Croatia, followed by Serbia and Slovenia, while Bosnia and Herzegovina according to the number of issued certificates is above F.Y.R. Macedonia and Montenegro.

Researches that were presented so far and many other implemented researches published reports indicate to a dissatisfaction of the users with the quality and with non-affirmative state in the public sector of Bosnia and Herzegovina, and therefore it is necessary to identify areas of the possible improvements.

In the public sector there is no market mechanism that would impose quality as a precondition for survival in the market, and therefore it is very good that units of the local self-government have recognized an importance of the citizens as users of public services, and therefore they based its business and business of public companies and institutions according to the modern principles of managing quality. The implementation of the systems for managing quality in the public sector of Bosnia and Herzegovina is still in the initial stages of its development, and promotion of it by institutions such as the Association for Quality in Bosnia and Herzegovina and the Institute for Standardization, the adoption of the Declaration about quality of the Council of Ministers, adoption of the Law on standardization of $\mathrm{BiH}$, launching initiatives to introduce BiH awards for quality, having annual thematic conferences about quality in the context of the European week of quality is a significant proof of the compatible acting of individuals and organizations with the European and global trends and expectations.

\section{Methodology and results}

The methodology is based on the collection and analysis of the subjective views of citizens for 16 public services which are exclusively within the jurisdiction, or for which there is a certain responsibility of local government, such as: water supply and 
sewerage, municipal hygiene, public heating, local streets and roads (including horizontal and vertical signalling), public lighting, green areas and parks, cemeteries, public transport, pre-school education, primary education, secondary education, libraries, access to the internet network, primary health care, social welfare services and services of the front office. Each of them is judged through a set of specific issues, therefore in the questionnaire a total of 54 characteristics are evaluated of above mentioned 16 public services. Citizens as users of public services had the opportunity to rate their satisfaction or dissatisfaction with these services through expressions ratings on a scale of 1 to 5, in which (1) indicates the answer "not at all satisfactory" and (5) "fully satisfactory". Observed according to evaluation grades, which this research showed, in the Table 4 are presented the best five and worst evaluated characteristics of the public service.

Table 4 The best and the worst five evaluated characteristics of the public service

\begin{tabular}{|c|l|c|l|c|}
\hline \multirow{2}{*}{ No. } & \multicolumn{2}{|c|}{ Che best evaluated characteristics } & \multicolumn{2}{|c|}{ The worst evaluated characteristics } \\
\cline { 2 - 5 } & $\begin{array}{c}\text { Average } \\
\text { grade }\end{array}$ & \multicolumn{2}{|c|}{ Characteristic } & $\begin{array}{c}\text { Average } \\
\text { grade }\end{array}$ \\
\hline 2 & at home the internet & 4.26 & $\begin{array}{l}\text { Volunteerism in maintenance } \\
\text { of green areas and parks }\end{array}$ & 1.80 \\
\hline 3 & $\begin{array}{l}\text { Access to schools } \\
\text { (primary education) }\end{array}$ & 3.88 & $\begin{array}{l}\text { The availability and location of } \\
\text { children's playgrounds }\end{array}$ & $\begin{array}{l}\text { Public transport in the evening } \\
\text { hours }\end{array}$ \\
\hline 4 & $\begin{array}{l}\text { Maintenance of } \\
\text { cemeteries }\end{array}$ & 3.71 & $\begin{array}{l}\text { Maintenance of watercourses } \\
\text { (rivers and streams) }\end{array}$ & 2.17 \\
\hline 5 & $\begin{array}{l}\text { The quality of primary } \\
\text { education }\end{array}$ & 3.71 & $\begin{array}{l}\text { The availability and location of } \\
\text { sports facilities }\end{array}$ & 2.34 \\
\hline
\end{tabular}

Source: author's calculation.

The observation unit is a household living in the selected dwelling unit and serves as the sample. A household is considered every family or other community of persons who live together and spend their incomes on necessities. A survey unit (respondent) is the oldest person in the household who is most familiar with the services that improve the socio-economic living conditions. Sample testing was selected from the infinite basic set and is designed as a cluster pattern. Cluster sample falls into the category of samples based on the principles of probability with respect that the elements of the sample are selected randomly and is commonly used in the researches for which a complete list of population is not available, where the population is so scattered that selection of units from all subsets is too expensive, or in cases where the choice of units in the sample is connected with the problems of technical, organizational and financial nature (Fazlović, 2013).

Clusters for carrying out tests are all local communities in the area of target local government and for each of them, based on the estimation of population, representative sample of households is defined without repeating the method of simple random sampling. The basic research question is: Is there a statistically significant difference between the satisfaction of users of public services in local government units in BiH that have implemented a quality management system ISO 9001 and the local self-governments, which did not?

Data on customer's satisfaction are obtained in a way that 42 out of the 54 characteristics which were the subject of evaluation in 30 local government units are classified in six categories whereas within one category the aim was to unite the greater number of characteristics covered by the same criteria for evaluating a 
large number of public services, while 12 of them, due to the heterogeneity were not possible to combine by the common element, and therefore are not subject for further consideration. In this sense, the characteristics are classified into categories that included these features:

- Quality: water quality (drinking water), the quality of heating (temperature in the house), the quality of public transport, quality of preschool education, the quality of primary education, the quality of secondary education, the quality of the content within the library service quality and primary health care and quality of front office service;

- Maintenance: maintenance of watercourses, rivers and streams, maintenance of streets and roads, maintenance of vertical and horizontal signalization, maintenance of public lighting, maintenance of green areas and parks and maintenance of cemeteries;

- Access: the access of the public transport, access of preschool education, access to schools (primary education), access to the library, access to the internet at home, the access to medical clinic (ambulance), access to social protection and services of front office;

- Availability: the availability and accessibility of containers and garbage cans, the availability and location of sports facilities, the availability and location of children's playgrounds, the availability of graves and availability of interests (secondary education);

- Cost: cost of services of water supply and sewage systems, the cost of services and collection of garbage, the cost of heating, the cost of burial sites, the cost of public transport, the cost of pre-school education and the cost of the Internet;

- Regularity and timeliness of delivery: regular water supply, timeliness in waste disposal, accuracy in supply heating, cleaning of streets and roads during the winter period, the periodicity of public transport, public transport in the evening hours and regularity of primary health care services (frequency doctors' visits and the provision of services).

As for the independent variable, while the categorization of units of local selfgovernment, database of certified organizations in BiH was taken into account, published on the website of the Institute for Standardization in $\mathrm{BiH}$, the base of certified organizations in BiH Foreign Trade Chamber of Bosnia and Herzegovina, and the official website of local self-governments.

By using statistical analysis, IBM SPSS Statistics 21 and parametric techniques T-test for independent samples were obtained the results shown in Table 5 and Table 6.

In Table 5, group statistics by all defined criteria are shown the mean values of users' satisfaction, standard deviations, values of satisfaction of users of public services from the average value and the standard error mean for 18 local selfgovernment units which in their operations have implemented a quality management system ISO 9001 and 12 of them who do not have it. In absolute terms, customer's satisfaction in all six categories is increased in local self-government units, which in its operations have implemented a quality management system ISO 9001.

According to Table 6, in the first part of the Independent Samples Test the results of Levene's test of equality of variances in two groups of local self-governments are given. When significance (see Levene's Test for Equality of Variances) is greater than 0.05 , the data meet the assumption of equal variances which is in our case, the result in all six categories. 
Table 5 Group statistics of the impact of the implementation of ISO 9001 standard to the satisfaction of users of public services

\begin{tabular}{|c|c|c|c|c|c|}
\hline Category & ISO & $\mathrm{N}$ & Mean & Std. Deviation & Std. Error Mean \\
\hline \multirow{2}{*}{ Quality } & (1) & 18 & 3.3311 & .30191 & .07116 \\
\hline & (2) & 12 & 3.0433 & .36977 & .10674 \\
\hline \multirow{2}{*}{ Maintenance } & (1) & 18 & 2.8661 & .32585 & .07680 \\
\hline & (2) & 12 & 2.6317 & .23988 & .06925 \\
\hline \multirow[b]{2}{*}{ Access } & (1) & 18 & 3.4128 & .30314 & .07145 \\
\hline & (2) & 12 & 3.1875 & .26870 & .07757 \\
\hline \multirow{2}{*}{ Availability } & (1) & 18 & 2.9661 & .33449 & .07884 \\
\hline & (2) & 12 & 2.6800 & .31886 & .09205 \\
\hline \multirow{2}{*}{ Cost } & (1) & 18 & 3.0278 & .23178 & .05463 \\
\hline & (2) & 12 & 2.9283 & .22041 & .06363 \\
\hline \multirow{2}{*}{ Regularity and timeliness of delivery } & (1) & 18 & 3.0989 & .35088 & .08270 \\
\hline & (2) & 12 & 2.9525 & .31421 & .09071 \\
\hline
\end{tabular}

Source: author's calculation.

NOTE: (1) = the results of the local self-governments with the implemented standard ISO 9001, (2) = the results of the local self-governments that have not implemented the standard ISO 9001

Table 6 Test of independent samples investigating the effects of the implementation of quality management system to the satisfaction of users of public services

\begin{tabular}{|c|c|c|c|c|c|c|c|c|}
\hline \multicolumn{3}{|c|}{ Category } & \multicolumn{2}{|c|}{ Quality } & \multicolumn{2}{|c|}{ Maintenance } & \multicolumn{2}{|c|}{ Access } \\
\hline & & & (1) & (2) & (1) & (2) & (1) & (2) \\
\hline \multirow{2}{*}{$\begin{array}{l}\text { Levene's } \\
\text { Test }\end{array}$} & \multicolumn{2}{|l|}{$\begin{array}{l}F \\
\text { civis }\end{array}$} & .456 & & 2.440 & & .510 & \\
\hline & \multicolumn{2}{|l|}{ Sig. } & .505 & & .130 & & .481 & \\
\hline \multirow{7}{*}{$\begin{array}{l}\text { t-test for } \\
\text { Equality } \\
\text { of Means }\end{array}$} & \multicolumn{2}{|l|}{$\dagger$} & 2.338 & 2.243 & 2.132 & 2.267 & 2.084 & 2.136 \\
\hline & \multicolumn{2}{|l|}{ df } & 28 & 20.349 & 28 & 27.642 & 28 & 25.641 \\
\hline & \multicolumn{2}{|c|}{ Sig. (2-tailed) } & .027 & .036 & .042 & .031 & .046 & .042 \\
\hline & \multirow{2}{*}{\multicolumn{2}{|c|}{$\begin{array}{l}\text { Mean Difference } \\
\text { Std. Error Difference }\end{array}$}} & .28778 & .28778 & .23444 & .23444 & .22528 & .22528 \\
\hline & & & .12307 & .12829 & 10997 & 10341 & .10811 & .10546 \\
\hline & \multirow{2}{*}{$95 \% \mathrm{CID}$} & Lower & .03567 & .02046 & .00918 & .02249 & .00382 & .00835 \\
\hline & & Upper & .53988 & .55509 & .45971 & .44640 & .44674 & .44220 \\
\hline & \multicolumn{2}{|c|}{ Category } & \multicolumn{2}{|c|}{ Availability } & \multicolumn{2}{|c|}{ Cost } & \multicolumn{2}{|c|}{$\begin{array}{c}\text { Regularity and } \\
\text { timeliness of delivery }\end{array}$} \\
\hline & & & (1) & (2) & (1) & (2) & (1) & (2) \\
\hline \multirow{2}{*}{$\begin{array}{c}\text { Levene's } \\
\text { Test }\end{array}$} & \multicolumn{2}{|l|}{$\mathrm{F}$} & .013 & & .019 & & .073 & \\
\hline & \multicolumn{2}{|l|}{ Sig. } & .910 & & .892 & & .789 & \\
\hline \multirow{7}{*}{$\begin{array}{l}\text { t-test for } \\
\text { Equality } \\
\text { of Means }\end{array}$} & \multicolumn{2}{|l|}{$t$} & 2.337 & 2.361 & 1.174 & 1.186 & 1.166 & 1.193 \\
\hline & \multicolumn{2}{|l|}{ df } & 28 & 24.521 & 28 & 24.561 & 28 & 25.492 \\
\hline & \multicolumn{2}{|c|}{ Sig. (2-tailed) } & .027 & .027 & .250 & .247 & .254 & .244 \\
\hline & \multicolumn{2}{|c|}{ Mean Difference } & .28611 & .28611 & .09944 & .09944 & .14639 & .14639 \\
\hline & \multicolumn{2}{|c|}{ Std. Error Difference } & .12240 & .12120 & .08474 & .08386 & .12557 & .12275 \\
\hline & \multirow{2}{*}{$95 \% \mathrm{CID}$} & Lower & .03538 & .03626 & -.07414 & -.07343 & -.11084 & -.10617 \\
\hline & & Upper & .53684 & .53597 & .27303 & .27232 & .40362 & .39895 \\
\hline
\end{tabular}

Source: author's calculation.

NOTE: (1) = equal variance; $(2)$ = variances are not equal; $C I D=$ Confidence Interval of the Difference

The criteria for determining the existence of statistically significant difference in customer's satisfaction in quality of public services between two groups of local government units is calculated in column Sig.(2-tailed) in section t-test for Equality of Means. When the value calculated in this row is equal to or less than 0.05 , than there is a statistically significant difference between the mean values of the dependent 
variable in two observed groups. In our case, a statistically significant difference between users of public services satisfaction exists when it comes to quality, maintenance, accessibility and availability of public services. But, when it comes to prices and the regularity and timeliness of delivery this difference is not statistically significant.

\section{Conclusions}

An analysis of the current situation in the public sector of Bosnia and Herzegovina through a series of published reports shows problematic quality of public services which are often burdened with unnecessary costs which are causing user's dissatisfaction. Traditional approach to these costs threatens that these services become one of the limiting factor for the overall development and not only at national but also at international level, and especially in the context of European integration processes. The achievement of quality in the public sector today is most often left to the coincidence and individual initiatives, and often we have witnessed an extremely bureaucratic and unreformed public organizations in which there is no natural signs of quality management.

As a way out of the current situation, and positive action towards improving the quality of services that is provided by the public sector, a set of guidelines and recommendations in the reports suggests the implementation of a quality management system. It is about establishing a systematic environment focused on quality and sustainable process of quality management in public organizations, emphasizing the principle of customer's satisfaction.

Based on the presented results of the research, it can be concluded that in the units of local government with implemented quality management system ISO 9001 it was recorded higher level of customer satisfaction than it was the case with units of local self-governments that did not enforced this at all. In fact, out of the six dimensions of the public services, which were the subject of analysis, greater customer satisfaction was recorded in four of them, and those are: quality dimension, maintenance, accessibility and availability of public services. In all four of them, as demonstrated by the results of the research, was recorded a statistically significant difference in the average evaluation of customer satisfaction in the units of local self-government that incorporated this international standard in its business activities in relation to those which did not carried it out. In the other two dimensions, prices and delivery on time as well as regular delivery, was not recorded statistically significant difference in the average score of customer satisfaction. However, if we take into account the greater heterogeneity of the public services characteristics which are covered by the dimension - delivery on time and regular delivery in relation to other dimensions, as well as the fact that the cost of public services largely are matter of political issues, therefore results of these two dimensions are as expected.

The research was carried out with the restriction that 16 categories of the public services were part of the project that was used as the basis of this research, and these VERN

categories are identified as most important for improvement of life quality of the citizens' at the local level. Regarding this, further researches may be directed to the inclusion of a large number of public services (higher education, cultural and sports services, maintenance of the public order, etc.), as well as a large number of indicators of public services which are covered by this research in order to consider it more comprehensively customer's satisfaction and identify areas of potential improvements. 


\section{References}

1. Babić-Hodović, V., Činjarević, M. (2008). Mjerenje percepcije kvaliteta usluga upotrebom SERVQUAL modela na primjeru usluga edukacije Ekonomskog fakulteta. Zbornik radova Ekonomskog fakulteta u Sarajevu, Vol. 28, pp. 28-46.

2. Babić-Hodović, V., Činjarević, M. (2009). Uticaj percepcije kvaliteta usluga edukacije na lojalnost klijenata. Zbornik 6. Naučno-stručnog skupa sa međunarodnim učešćem „Kvalitet 2009", pp. 737-744.

3. Boulding, W., Karla, A., Staelin, R., Zeithaml, W.A. (1993). A Dynamic, Process Model of Service Quality: From Expectations to Behavioural Intentions. Journal of Marketing Research, Vol. 30, pp. 7-27.

4. Fazlović, S. (2013). Primijenjena statistika. OFF SET, Tuzla.

5. Gorji, M., Sargolzaee, S. (2011). The study of the relation between service quality and customer satisfaction the based on servqual model. International Conference on Ebusiness, Management and Economics, Vol. 25, pp. 191-196.

6. Stringham, S. H. (2004). Does quality management work in the public sector. Public Administration and Management: An Interactive Journal, Vol. 9, No. 3, pp. 181-211.

7. Huseinspahić, N. (2010). Mjerenje funkcionalne dimenzije kvaliteta usluga u zdravstvu korištenjem SERVQUAL modela. BH Ekonomski forum, Ekonomski fakulteł U Zenici, Vol. 1/2010, pp. 41-59.

8. llić, M., Živković, Z. (2011). Kvalitet rada javnih preduzeća grada Beograda po oceni potrošača-korisnika usluga, Zbornik radova 38. Nacionalne konferencije o kvalitetu. pp. A177-183.

9. International Organization for Standardization. (2014). Iso Survey-evolution of ISO 9001 certificates in Bosnia and Herzegovina. Available at http://www.iso.org/iso/home/ standards/certification/iso-survey.htm? certificate=ISO\%209001 \&countrycode=BA\#cou ntrypick [10 June 2016].

10.International Organization for Standardization. (2014). Iso Survey-evolution of ISO 9001 certificates in Croatia. Available at http://www.iso.org/iso/home/standards/ certification/iso-survey.htm? certificate=ISO\%209001 \& countrycode=HR\#countrypick $\quad[10$ June 2016].

11.International Organization for Standardization. (2014). Iso Survey-evolution of ISO 9001 certificates in Montenegro. Available at http://www.iso.org/iso/home/standards/ certification/iso-survey.htm? certificate=ISO\%209001 \&countrycode=ME\#countrypick $\quad[10$ June 2016].

12.International Organization for Standardization. (2014). Iso Survey-evolution of ISO 9001 certificates in The Former Yugoslav Republic of Macedonia. Available at http://www.iso.org/iso/home/standards/certification/iso-survey.htm? certificate=lSO\% 209001 \& countrycode=MK\#countrypick [10 June 2016].

13.International Organization for Standardization. (2014). Iso Survey-evolution of ISO 9001 certificates in Slovenia. Available at http://www.iso.org/iso/home/standards/ certification/iso-survey.htm? certificate=ISO\%209001\&countrycode=SI\#countrypick $\quad[10$ June 2016].

14.International Organization for Standardization. (2014). Iso Survey-evolution of ISO 9001 certificates in Serbia. Available at http://www.iso.org/iso/home/standards/ certification/iso-survey.htm? certificate=ISO\%209001\&countrycode=RS\#countrypick $\quad[10$ June 2016].

15.Kakeš, D. (2014). Unapređenje kvaliteta usluga u javnom sektoru Bosne i Hercegovine implementacijom sistema upravljanja kvalitetom. Master thesis, Ekonomski fakultet, Univerzitet u Tuzli.

16. Oliver, R. L. (1981). A Cognitive Model of the Antecedents and Outcomes of Satisfaction Decision. Journal of Retailing. Vol. 57, No. 3, pp. 25-48.

17.Otajagić, F. (2011). Kvalitet upravljanja $u$ javnom sektoru Bosne i Hercegovine. Zbornik radova 7. Naučno stručnog skupa sa međunarodnim učešćem „Kvalitet 2011“, pp. 10031010. 
18.Ramseook-Munhurrun, P., Lukea-Bhiwajee, S. D., Naidoo, P. (2010). Service quality in the public service. International Journal of Management and Marketing research. Vol. 3, No. 1, pp. 37-50.

19.Razvojna Agencija EDA Banja Luka (2006). Strateški plan razvoja lokalne samouprave u $\mathrm{BiH}$. Available at http://www.sogfbih.ba/uploaded/download/Strateski\%20plan\%20 razvoja\%20lokalne\%20samouprave\%20u\%20BiH.pdf [10 June 2016].

20.Skoko, H. (2000). Upravljanje kvalitetom. Sinergija, Zagreb.

21.Šehić, Dž. (2002). Strateški menadžment. Slovo, Mostar.

22. Transparency International BiH (2009). Korupcija u Bosni i Hercegovini. Available at http://tibih.org/wp-content/uploads/2011/02/Korupcija_U_BiH.pdf [01 June 2016].

23. Transparency International BiH (2012). Nalazi istraživanja o transparentnosti jedinica lokalne samouprave u Bosni i Hercegovini 2012. Available at http://www.civilsocietylibrary.org/CSL/591/Nalazi-istrazivanja-o-transparentnosti-jedinicalokalne-samouprave-u-Bosni-i-Hercegovini-2012 [11 June 2016].

24.Woodside, A.G., Frey, L.L., Daly, R.T. (1989). Linking Service Quality, Customer Satisfaction, and Behavioral Intention. Journal of Health Care Marketing. Vol. 9, No. 4, pp. 5-17.

\section{About the authors}

Dino Kakeš graduated at Faculty of Economics, University of Tuzla and obtained a Master of Science degree at the same institution. Recipient of the Tuzla University Silver Medal. Works as associate since 2009, first as assistant, than as an expert from practice and today as a senior teaching assistant at the Faculty of Economics Tuzla, and has experience in undergraduate, as well as postgraduate study level. In this period, he also worked at the Faculty of Special Education, Rehabilitation, and Faculty of Technology. Since September 2009, he is employed at Indirect Taxation Authority, first as associate and today as a senior associate-inspector in the Group for Control of Large Taxpayers Tuzla. He can be contacted at dino_kakes@hotmail.com.

Senad Fazlović has twenty-three years of successful academic career. He has gone through all associate and teaching titles. Since February 2014, he holds a title of Full Professor in the field of Quantitative Economics. In previous work, he worked at all three study cycles at the Faculty of Economics, Faculty of Special Education and Rehabilitation, Faculty of Technology, Faculty of Medicine, Faculty of Sciences and Mathematics, Faculty of Pharmacy and Faculty of Law. He is focused on the teaching and the research in the field of the statistics and quality management, where he has made significant accomplishments and meaningful contribution to the theory and practice. As an author and co-author, he has published 6 books and over 60 scientific papers published in the recognized journals and presented at the respectful international and national conferences. He can be contacted at senad.fazlovic@untz.ba. 